\title{
Extensive spontaneous spinal epidural haematoma: when 'treatment turned to tragedy'
}

\author{
Nishanth Selvaraj, Anand Chellappan, Deepanjali Surendran, \\ Swaminathan Rathinam Palamalai
}

Department of Medicine, Jawaharlal Institute of Postgraduate Medical Education and Research ( JPMER), Pondicherry, India

\section{Correspondence to} Dr Anand Chellappan, anandthedoc@gmail.com

Accepted 8 February 2015
CrossMark

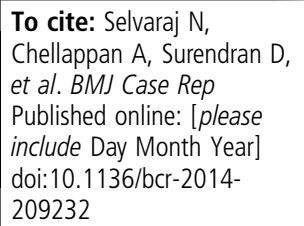

\section{DESCRIPTION}

A 30-year-old woman presented with acute onset of severe low back pain associated with weakness of both the lower limbs and retention of urine. She was a known case of rheumatic heart disease, mitral regurgitation and atrial fibrillation on anticoagulation with warfarin. Her weakness had ascended rapidly to the trunk and upper limbs. Examination revealed flaccid paralysis with bilateral extensor plantar response. Acute cord compression was suspected and MRI of the spine was performed, which revealed acute epidural haematoma extending from C6 to T10 (figure 1). Her international normalised ratio was 4.5. Emergency neurosurgical intervention was planned. Coagulopathy was corrected with fresh frozen plasma transfusion. A laminectomy was performed and haematoma evacuated. The patient's power improved to grade $3 / 5$ at discharge.

Spontaneous spinal epidural haematoma (SSEH) is a rare but disabling neurological condition with an annual incidence of 0.1 cases per 100000 individuals. ${ }^{1}$ Cervicothoracic and thoracolumbar regions are commonly affected. The pathogenesis of SSEH is largely unknown. Anticoagulation acts as a precipitating factor in $17 \%$ of cases. Anticoagulant therapy alone does not trigger spinal haemorrhage. An additional 'locus minoris resistentiae', or network of weakened epidural veins, is implicated along with increased pressure in the internal vertebral venous plexus. ${ }^{2}$ Owing to lack of valves in the epidural veins, an increase in intra-abdominal or intrathoracic pressure in situations such as coughing, straining or voiding may cause bulk of backflow resulting in the rupture of veins.

SSEH presents with intense, knife-like pain ('coup de poignard') at the level of haemorrhage followed by progressive paralysis below the affected level. Early and definitive diagnosis can be achieved with the help of MRI. Axial images give information on the degree of compression whereas sagittal images give information on the extent of the lesion. The common differentials include spinal epidural abscess, spinal cord tumour, herniated disc and spinal subdural haematoma.
A

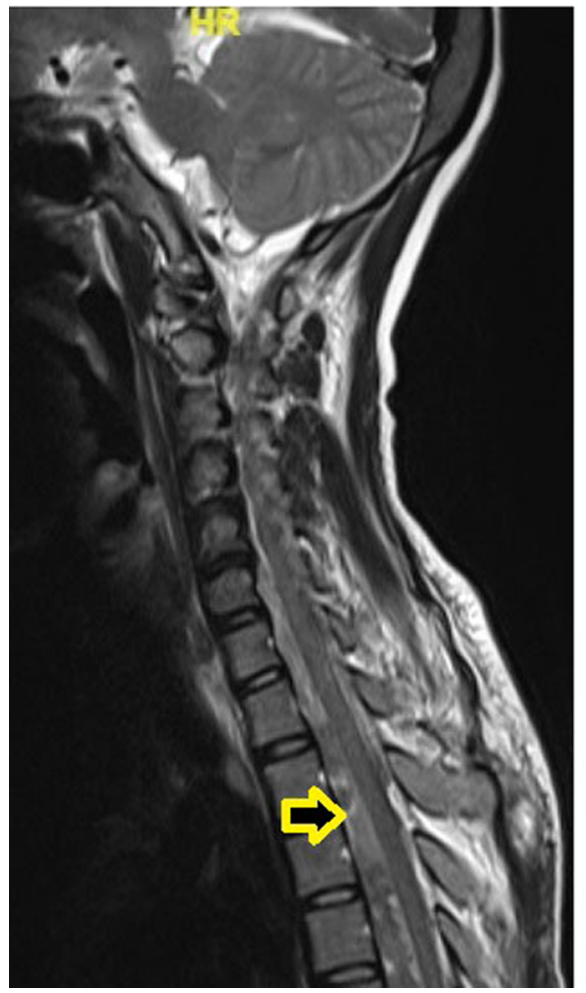

B

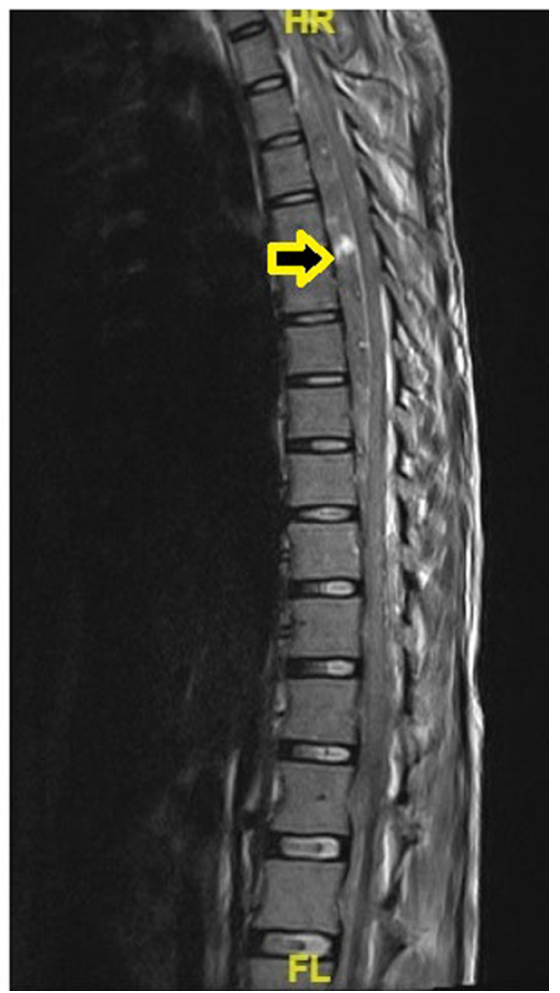

Figure 1 T2 sagittal MRI showing epidural haematoma (arrow) extending (A) from C6 and (B) over the thoracic cord up to $\mathrm{T} 10$ level. 
SSEH is a neurosurgical emergency. Emergency laminectomy or laminotomy with haematoma evacuation is the preferred treatment. Coagulopathy due to anticoagulant use should be treated prior to surgery. Most benefit is derived from surgical relief of compression within $12 \mathrm{~h}$ of onset of the symptoms. ${ }^{3}$

\section{Learning points}

Spontaneous spinal epidural haematoma (SSEH) is a rare disease.

- SSEH associated with anticoagulant use is uncommon in the absence of a 'locus minoris resistentiae'.

- SSEH presents with intense, knife-like pain ('coup de poignard') and progressive paralysis below the affected level.

- SSEH is a neurosurgical emergency. Early identification with $\mathrm{MRI}$ and haematoma evacuation can prevent permanent neurodeficit.
Acknowledgements The authors thank the Departments of Radiology and Neurosurgery, JIPMER, for their support in the management of this case.

Contributors $A C$ was involved in the treatment of the patient and preparation of the manuscript. DS and SRP were involved in the treatment of the patient. NS was involved in the treatment of the patient and reviewing the literature on this case.

Competing interests None.

Patient consent Obtained.

Provenance and peer review Not commissioned; externally peer reviewed.

\section{REFERENCES}

1 Holtås S, Heiling M, Lönntoft M. Spontaneous spinal epidural hematoma: findings at MR imaging and clinical correlation. Radiology 1996;199:409-13.

2 Groen RJ, Ponssen H. The spontaneous spinal epidural hematoma. A study of the etiology. J Neurol Sci 1990;98:121-38.

3 Kreppel $D$, Antoniadis $G$, Seeling W. Spinal hematoma: a literature survey with meta-analysis of 613 patients. Neurosurg Rev 2003;26:1-49.

Copyright 2015 BMJ Publishing Group. All rights reserved. For permission to reuse any of this content visit http://group.bmj.com/group/rights-licensing/permissions.

BMJ Case Report Fellows may re-use this article for personal use and teaching without any further permission.

Become a Fellow of BMJ Case Reports today and you can:

- Submit as many cases as you like

- Enjoy fast sympathetic peer review and rapid publication of accepted articles

- Access all the published articles

- Re-use any of the published material for personal use and teaching without further permission

For information on Institutional Fellowships contact consortiasales@bmjgroup.com

Visit casereports.bmj.com for more articles like this and to become a Fellow 